\title{
Breastfeeding practice in the Brazilian capital cities and the Federal District: current status and advances
}

\author{
Sonia I. Venancio, ${ }^{1}$ Maria M. L. Escuder, ${ }^{2}$ Sílvia R. D. M. Saldiva, ${ }^{3}$ Elsa R. J. Giugliani ${ }^{4}$
}

Objectives: To present the breastfeeding (BF) indicators obtained in the Second Survey on Prevalence of Breastfeeding in the Brazilian Capitals and the Federal District and to analyze their evolution from 1999 to 2008.

Methods: A cross-sectional study was conducted in children younger than 1 year old who participated in the second phase of the multivaccination campaign in 2008. We used two-stage cluster sampling. The questionnaire consisted of closed questions, including data on consumption of breast milk, other types of milk, and other foods on the day prior to the survey. We analyzed the prevalence of $\mathrm{BF}$ in the first hour of life; exclusive $\mathrm{BF}$ in children younger than 6 months; $\mathrm{BF}$ in children aged 9 to 12 months; and medians of exclusive BF and BF. The time variation of BF was established by comparing the medians of exclusive BF and BF in 1999 and 2008.

Results: We obtained data from 34,366 children. We found that $67.7 \%$ (95\%CI $66.7-68.8$ ) of the children were breastfed in the first hour of life; the prevalence of exclusive BF in children aged 0 to 6 months was $41 \%$ (95\%CI 39.7-42.4), while the prevalence of BF in children aged 9 to 12 months was $58.7 \%$ (95\%CI 56.8-60.7). There was an increase of 30.7 days in the median duration of exclusive BF and 45.7 days in the median of BF.

Conclusion: There was a significant improvement in the breastfeeding prevalence in the last decade. However further efforts are required so that Brazil can reach BF rates compatible with the recommendations of the World Health Organization.

J Pediatr (Rio J). 2010;86(4):317-324: Breastfeeding, exclusive breastfeeding, cross-sectional study, indicators.

\section{Introduction}

Breastfeeding (BF) is the best strategy to prevent child deaths, ${ }^{1}$ in addition to promoting physical, mental, and emotional health of children. It is estimated that BF can reduce by $13 \%$ the deaths of children under 5 years ${ }^{1}$ and by 19 to $22 \%$ the neonatal deaths if practiced in the first hour of life. ${ }^{2,3}$ Therefore, promotion of BF should be included among priority health actions.

Brazil has been investing in the promotion of BF since 1981 with the establishment of the National Program of
Breastfeeding Incentive, considered a model because of the diversity of actions. ${ }^{4}$ Thanks to national studies, it is evident that BF rates have been gradually increasing in Brazil. Venancio \& Monteiro ${ }^{5}$ demonstrated an increase in BF duration between 1974 and 1989 , from 2.5 to 5.5 months. ${ }^{5}$ Data from the National Surveys on Demography and Health (Pesquisas Nacionais sobre Demografia e Saúde - PNDS) confirmed this trend, identifying increases in the BF median from 7 months in $1996^{6}$ to 14 months in $2006 .^{7}$

1. Doutora. Pesquisadora, Instituto de Saúde, Secretaria Estadual de Saúde de São Paulo (SES-SP), São Paulo, SP, Brazil.

2. Mestre. Pesquisadora, Instituto de Saúde, SES-SP, São Paulo, SP, Brazil.

3. Doutora. Pesquisadora, Instituto de Saúde, SES-SP, São Paulo, SP, Brazil.

4. Doutora. Professora associada, Universidade Federal do Rio Grande do Sul (UFRGS), Porto Alegre, RS, Brazil.

This study was conducted at the Health Institute, São Paulo State Department of Health (Secretaria Estadual de Saúde de São Paulo, SES-SP), São Paulo, SP, Brazil.

Financial support: Brazilian Ministry of Health.

No conflicts of interest declared concerning the publication of this article.

Suggested citation: Venancio SI, Escuder MM, Saldiva SR, Giugliani ER. Breastfeeding practice in the Brazilian capital cities and the Federal District: current status and advances. J Pediatr (Rio J). 2010;86(4):317-324.

Manuscript received Dec 21 2009, accepted for publication May 122010.

doi:10.2223/JPED.2016 
The first information on the status of exclusive breastfeeding (EBF) in Brazil was provided by a study conducted in 1986, which demonstrated that only $3.6 \%$ of the children between 0 and 4 months were exclusively breastfed. ${ }^{8}$ Data from 2006 showed EBF prevalence of $38.6 \%$ in children under 6 months. ${ }^{7}$

In 1999, the first survey on the prevalence of BF was conducted in the Brazilian capital cities and the Federal District (FD) during a national vaccination campaign. There was a prevalence of $35.6 \%$ of EBF in children under 4 months and a BF median duration of 10 months. ${ }^{9}$

In 2008, with the support of the Brazilian Ministry of Health, the Second National Survey of BF Prevalence (II PPMA) was conducted ${ }^{10}$ using the same methodology employed in the 1999 survey. The reason for conducting the survey was the need managers had to obtain an analysis of the progress in the BF status, considering the various actions carried out within the scope of the national policy. The present article presents data related to the key indicators of BF in the Brazilian capital cities and the FD and analyzes its evolution from 1999 to 2008.

\section{Methods}

This is a cross-sectional study involving children younger than 1 year old who participated in the 2008 multivaccination campaign held in all Brazilian capital cities and the FD.

Personnel of the State and City Departments of Health were trained during three 16 -hour workshops that prepared the professionals to carry out all stages of the study. Participants received support manuals containing guidelines for municipal coordinators, field supervisors, and interviewers.

The questionnaire was administered using two-stage cluster sampling and probability proportional to size of clusters. In the first stage, the vaccination centers were randomly selected, and in the second stage, children from each center were randomly selected. ${ }^{11}$ Samples were planned based on information provided by the states: number of vaccination centers in each capital city and number of children under 1 year old vaccinated at each center in 2007. The sample size took into consideration the prevalence of EBF in the capital cities and the FD in 1999 , with an additional number of 2 to $10 \%$, based on the predicted increase in prevalence. To compensate for the accuracy losses inherent to cluster sampling, we added the design effect, multiplying the initial estimate by 1.5 , and also considering a non-response rate of 5 to $10 \%$. The sample size required to estimate the EBF in children under 6 months was multiplied by 2 .

The questionnaire included closed questions about the consumption of breast milk, other types of milk, and other foods, including water, teas and other liquids, on the day prior to the survey. The use of current status, recommended by the World Health Organization (WHO), ${ }^{12}$ aims to minimize possible biases resulting from the informant's memory, which is particularly suitable for the characterization of EBF. This instrument was administered by previously trained interviewers to all caregivers of children younger than 1 year old during the second stage of the 2008 multivaccination campaign. The interviews took place during the whole day of the campaign and, in the cities where vaccination activities were held before or after the scheduled date, interviewers were instructed to carry out data collection during the entire campaign period.

The municipalities were responsible for data entry into an online application developed to this end. Databases of capital cities and the FD were subsequently exported to an SPSS 16.0 database.

Specific procedures were used for the analysis of the questionnaires with complex probability sampling. Prevalence estimates consider the standard error determined by the sampling design and their respective $95 \%$ confidence intervals ( $95 \% \mathrm{CI})$. Because of population differences between the capital cities involved, each plan represented a different sampling fraction, represented by the estimated sample size on the number of children being vaccinated. The inverse of this fraction was used to calculate regional prevalence rates and prevalence rates for all capital cities.

We analyzed the following indicators proposed by the $\mathrm{WHO}^{12}$ : $\mathrm{BF}$ in the first hour of life; $\mathrm{EBF}$ in children under 6 months old; continued BF; and median duration of EBF and BF. Children were considered to be under EBF when they received only breast milk without any other foods or liquids, including water and tea; and children being breastfed where those who had received breast milk, regardless of other foods. The medians of EBF and BF were obtained by logit analysis, which estimates the probability of occurrence of the event being investigated based on age by means of statistical modeling.

Time variation of $\mathrm{BF}$ was established by comparing the medians of EBF and BF, based on data published in the 1999 and 2008 studies. We calculated the difference of the indicator, in days, and its degree of evolution, in percentage, obtained by calculating: [(2008 median - 1999 median)/ median in $1999 \times 100]$. We found a statistically significant change when there was no overlap of the respective $95 \% \mathrm{CI}$.

We also tested the correlation between BF status in 1999 and the degree of evolution of the medians of EBF and BF. The results are presented in correlation graphs designed using the SPSS 16.0 software.

The study protocol was approved by the Research Ethics Committee of the Health Institute (protocol 001/2008 dated May 6, 2008), after consulting the National Research Ethics Committee (CONEP). 


\section{Results}

We included 34,366 children in the present study. There was a slight male predominance $(50.4 \%)$ and a larger number of children up to 6 months of age (55.4\%). Most mothers were between 20 and 35 years old $(72.2 \%)$, and the percentage of mothers under the age of 20 years old was $17.2 \% ; 86.2 \%$ of the mothers had under 12 years of schooling and $24.9 \%$ had less than 8 years of educational level; $66.2 \%$ did not have out-of-home jobs, $11.9 \%$ were on maternity leave, and $21.9 \%$ had a job when the interview was made.

Table 1 shows the indicators "BF in the first hour of life," "EBF in children under 6 months," and "BF in children from 9 to 12 months."
We found that $67.7 \%$ of the children had been breastfed in the first hour of life; the North, Central West and South regions showed the best results $(72.9,72.0$, and $71.8 \%$, respectively), and the Southeast region had the lowest percentage of children in this condition (63.5\%). The comparison between the capital cities demonstrated that São Luís had the best rate (83.5\%) whereas Salvador had the worst rate $(58.5 \%)$. Worth of notice was the fact most capital cities (17) showed rates higher than the mean for all children studied.

EBF prevalence in children under 6 months was $41 \%$ in all capital cities and the FD; the North region showed the highest prevalence rate $(45.9 \%)$, followed by the Central West $(45.0 \%)$, South $(43.9 \%)$, and Southeast $(39.4 \%)$

Table 1 - Main breastfeeding indicators (Brazil, regions and capital cities, 2008)

\begin{tabular}{|c|c|c|c|c|c|c|}
\hline \multirow[b]{2}{*}{ Region/capital city } & \multicolumn{2}{|c|}{$\begin{array}{c}\text { BF in the first hour } \\
\text { of life }\end{array}$} & \multicolumn{2}{|c|}{$\begin{array}{c}\text { EBF in children under } \\
6 \text { months }\end{array}$} & \multicolumn{2}{|c|}{$\begin{array}{c}\text { BF in children } \\
\text { from } 9 \text { to } 12 \text { months }\end{array}$} \\
\hline & $\%$ & $95 \% \mathrm{CI}$ & $\%$ & $95 \% \mathrm{CI}$ & $\%$ & $95 \% \mathrm{CI}$ \\
\hline North & 72.9 & $70.0-75.0$ & 45.9 & $42.9-49.0$ & 76.9 & $73.8-80.0$ \\
\hline Belém & 72.8 & $69.2-76.1$ & 56.1 & $50.2-61.9$ & 79.9 & $72.5-87.3$ \\
\hline Boa Vista & 77.5 & 74.9-79.9 & 40.7 & $35.8-45.7$ & 74.2 & $68.2-80.2$ \\
\hline Macapá & 75.8 & $73.4-78.0$ & 43.1 & $39.1-47.1$ & 82.8 & $78.2-87.3$ \\
\hline Manaus & 71.9 & $67.5-75.9$ & 41.1 & $37.4-44.9$ & 76.9 & $71.5-82.4$ \\
\hline Palmas & 79.6 & $76.6-82.3$ & 35.7 & $30.3-41.4$ & 67.9 & $61.7-74.0$ \\
\hline Porto Velho & 73.8 & $70.6-76.7$ & 36.4 & $31.1-42.1$ & 71.0 & $64.7-77.3$ \\
\hline Rio Branco & 64.3 & $58.4-69.8$ & 36.1 & $29.0-43.8$ & 62.9 & $51.8-73.9$ \\
\hline Northeast & 66.9 & $65.4-68.5$ & 37.0 & $35.0-39.0$ & 59.1 & $56.7-61.5$ \\
\hline Aracaju & 61.2 & $57.8-64.4$ & 35.0 & $29.0-41.5$ & 63.6 & 56.8-70.4 \\
\hline Fortaleza & 67.6 & $64.5-70.6$ & 32.9 & $29.0-37.0$ & 57.3 & $51.7-62.9$ \\
\hline João Pessoa & 76.9 & $73.5-80.0$ & 39.1 & $35.4-42.9$ & 53.1 & $45.7-60.5$ \\
\hline Maceió & 64.8 & $60.9-68.5$ & 34.0 & $28.8-39.5$ & 58.6 & $50.9-66.3$ \\
\hline Natal & 70.3 & $66.9-73.6$ & 40.5 & $36.7-44.4$ & 55.2 & 49.1-61.4 \\
\hline Recife & 66.8 & $63.0-70.4$ & 38.3 & $32.7-44.2$ & 59.1 & $52.7-65.5$ \\
\hline Salvador & 58.5 & $54.4-62.5$ & 36.5 & $32.3-40.9$ & 59.1 & $52.7-65.5$ \\
\hline São Luís & 83.5 & $79.8-86.6$ & 46.7 & $40.3-53.1$ & 76.9 & $70.4-83.4$ \\
\hline Teresina & 79.0 & $73.0-84.0$ & 43.7 & $38.4-49.3$ & 75.0 & 69.9-80.1 \\
\hline Central West & 72.0 & $69.8-74.0$ & 45.0 & $42.2-47.9$ & 64.1 & $60.3-67.9$ \\
\hline Campo Grande & 74.3 & $71.0-77.3$ & 50.1 & $44.7-55.4$ & 70.0 & $64.0-76.1$ \\
\hline Cuiabá & 77.4 & $72.3-81.8$ & 27.1 & $22.3-32.6$ & 66.4 & 59.0-73.8 \\
\hline Federal District & 72.5 & $69.3-75.4$ & 50.0 & $45.8-54.2$ & 65.4 & $60.1-70.8$ \\
\hline Goiânia & 66.7 & $63.1-70.0$ & 32.7 & $29.5-36.0$ & 53.8 & 48.1-59.5 \\
\hline Southeast & 63.5 & $61.3-65.7$ & 39.4 & $36.5-42.3$ & 51.4 & $47.8-55.0$ \\
\hline Belo Horizonte & 64.1 & $60.4-67.7$ & 37.9 & $33.2-42.9$ & 50.0 & $43.1-56.8$ \\
\hline Rio de Janeiro & 65.6 & $63.4-67.7$ & 40.7 & $37.3-44.2$ & 58.3 & $54.8-61.8$ \\
\hline São Paulo & 62.4 & $59.2-65.6$ & 39.1 & $35.0-43.3$ & 48.7 & 43.6-53.9 \\
\hline Vitória & 72.8 & $69.3-76.0$ & 44.0 & $39.8-48.3$ & 59.1 & $52.6-65.7$ \\
\hline South & 71.8 & $69.9-73.7$ & 43.9 & $41.1-46.7$ & 49.5 & $45.2-53.9$ \\
\hline Curitiba & 71.2 & $68.2-74.0$ & 46.1 & $41.6-50.6$ & 48.5 & 41.9-55.1 \\
\hline Florianópolis & 75.5 & $72.1-78.7$ & 52.4 & $47.9-56.9$ & 52.2 & $46.5-58.0$ \\
\hline Porto Alegre & 71.9 & $69.0-74.5$ & 38.2 & $35.2-41.3$ & 50.2 & 43.4-57.0 \\
\hline Brazil & 67.7 & $66.7-68.8$ & 41.0 & $39.7-42.4$ & 58.7 & 56.8-60.7 \\
\hline
\end{tabular}

$95 \% \mathrm{Cl}=95 \%$ confidence interval.

$\mathrm{BF}$ = breastfeeding; EBF = exclusive breastfeeding 
regions, with the Northeast region presenting the worst status (37.0\%). In relation to the capital cities, Belém stood out with the highest prevalence rate $(56.1 \%)$, followed by Florianópolis (52.4\%), Campo Grande (50.1\%), and the FD $(50.0 \%)$. On the other hand, the lowest prevalence rate was found in Cuiabá (27.1\%). It is noteworthy that most capital cities (17) had rates lower than the mean for all the children studied.

BF prevalence in children from 9 to 12 months was $58.7 \%$. The North region had the best status (76.9\%), followed by the Central West (64.1\%), Northeast (59.1\%), and Southeast $(51.4 \%)$ regions, with the South region showing the worst status (49.5\%). Regarding the capital cities, Macapá and Belém stood out with the highest prevalence rates (82.8 and $79.9 \%$, respectively), and
Curitiba showed the lowest rate (48.5\%). In 15 out of the 27 cities studied, the status was better than the mean found for all the children analyzed.

Table 2 shows comparative data on the median duration of EBF.

We found an increase of 1 month in the median duration of EBF in Brazil, from 23.4 days in 1999 to 54.1 days in 2008. The comparison between the regions showed significant increases in the Central West region (47.1 days), followed by the North (42.2 days) and Southeast (41.9 days) regions. In the South region, there was a less significant increase (20.2 days), and the Northeast region had the worst performance (8.6 days). In this region, there was increase in the EBF median in most capital cities, but with significant reduction in Fortaleza, which changed from 63.6

Table 2 - Evolution of the median duration of exclusive breastfeeding (Brazil, regions and capitals, 1999 to 2008)

\begin{tabular}{|c|c|c|c|c|c|c|}
\hline \multirow[b]{2}{*}{ Region/capital city } & \multicolumn{2}{|c|}{1999} & \multicolumn{2}{|c|}{2008} & \multirow[b]{2}{*}{$\Delta(\mathbf{b}-\mathbf{a})$} & \multirow{2}{*}{$\begin{array}{c}\text { Evolution } \\
\qquad(\%)\end{array}$} \\
\hline & Mediana & $95 \% \mathrm{CI}$ & Median'b & 95\%CI & & \\
\hline North* & 24 & $21.5-26.8$ & 66.2 & $61.3-70.9$ & 42.2 & 175.83 \\
\hline Manaus* & 7.6 & $2.6-22.4$ & 49.9 & $38.9-59.9$ & 42.3 & 556.58 \\
\hline Porto Velho* & 13.6 & $8.8-21.2$ & 59.4 & $47.9-69.3$ & 45.8 & 336.76 \\
\hline Boa Vista* & 19.2 & $13.4-27.5$ & 56.9 & $48.8-64.1$ & 37.7 & 196.35 \\
\hline Rio Branco & 14.1 & $9.4-21.0$ & 38.8 & $19.3-54.0$ & 24.7 & 175.18 \\
\hline Palmas* & 23.9 & $18.6-30.7$ & 57.2 & $44.2-68.0$ & 33.3 & 139.33 \\
\hline Macapá* & 42.1 & $36.9-48.1$ & 74.3 & $64.9-82.6$ & 32.2 & 76.48 \\
\hline Belém* & 56.1 & $45.6-68.9$ & 88.8 & $83.5-94.1$ & 32.7 & 58.29 \\
\hline Northeast* & 26.3 & $24.1-28.6$ & 34.9 & 29.5-39.9 & 8.6 & 32.70 \\
\hline Recife* & 6.8 & $1.9-24.3$ & 49.6 & $44.3-54.5$ & 42.8 & 629.41 \\
\hline Maceió & 8.2 & $4.8-14.2$ & 28.4 & $5.12-46.0$ & 20.2 & 246.34 \\
\hline João Pessoa* & 21.9 & $17.0-28.2$ & 61.1 & 51.9-69.2 & 39.2 & 179.00 \\
\hline Natal* & 25 & $19.3-32.4$ & 56.2 & $46.7-64.6$ & 31.2 & 124.80 \\
\hline Aracaju* & 24.6 & $19.2-31.4$ & 49.9 & $35.8-61.6$ & 25.3 & 102.85 \\
\hline Salvador & 15.4 & $10.1-23.4$ & 31.2 & 19.6-41.1 & 15.8 & 102.60 \\
\hline Teresina* & 33.4 & $27.4-40.8$ & 61.9 & 49.0-72.9 & 28.5 & 85.33 \\
\hline São Luís & 30.3 & $19.5-47.2$ & 55.7 & $37.9-70.3$ & 25.4 & 83.83 \\
\hline Fortaleza* & 63.6 & $58.4-69.2$ & 10.6 & $-0.5-20.1$ & -53.0 & -83.33 \\
\hline Central West & 19.5 & $17.1-22.3$ & 66.6 & $61.5-71.4$ & 47.1 & 241.54 \\
\hline Campo Grande* & 17.6 & $12.9-24.0$ & 78 & $70.5-85.1$ & 60.4 & 343.18 \\
\hline Goiânia* & 9.3 & $5.8-15.1$ & 38.6 & $29.1-46.8$ & 29.3 & 315.05 \\
\hline Federal District* & 45 & $40.1-50.5$ & 77.7 & $71.4-83.6$ & 32.7 & 72.67 \\
\hline Cuiabá & 5.1 & 2.5-10.5 & 0.7 & $-38.2-25.9$ & -4.4 & -86.27 \\
\hline Southeast* & 13.1 & 10.1-17.0 & 55 & $47.9-61.5$ & 41.9 & 319.85 \\
\hline Belo Horizonte* & 7.8 & $4.4-13.8$ & 53.8 & $42.3-63.8$ & 46.0 & 589.74 \\
\hline São Paulo* & 9.2 & $4.9-17.2$ & 54.8 & $44.3-64.0$ & 45.6 & 495.65 \\
\hline Vitória* & 26.7 & $20.8-37.2$ & 62.5 & $54.3-70.1$ & 35.8 & 134.08 \\
\hline Rio de Janeiro & - & - & 55.4 & $48.2-61.9$ & & \\
\hline South & 39.1 & $34.5-44.3$ & 59.3 & $51.0-66.8$ & 20.2 & 51.66 \\
\hline Porto Alegre* & 29.5 & $21.8-39.9$ & 51.8 & $40.9-61.3$ & 22.3 & 75.59 \\
\hline Curitiba* & 34.6 & $28.3-42.3$ & 59.7 & 45.7-71.6 & 25.1 & 72.54 \\
\hline Florianópolis* & 55.6 & $46.7-66.2$ & 86.5 & 79.4-93.2 & 30.9 & 55.58 \\
\hline Brazil* & 23.4 & $22.1-24.7$ & 54.1 & $50.3-57.7$ & 30.7 & 131.20 \\
\hline
\end{tabular}

$95 \% \mathrm{Cl}=95 \%$ confidence interval.

* Difference between statistically significant medians. 
days (the best indicator in 1999) to 10.6 days in 2008 . The analysis of this indicator shows that favorable changes were statistically significant in 20 capital cities. It is noteworthy that in Campo Grande there was an increase of 2 months in the median duration of EBF.

Table 3 shows the median duration of BF in the two studies.

The median duration of BF in Brazil increased about 1.5 months, from 295.9 days in 1999 to 341.6 days in 2008. The North region, where there was the longest BF duration in the 1999 study, was the only region where an increase of 20.6 days was not statistically significant. The Northeast region was the one that stood out in terms of $B F$ expansion, with an increase of approximately 3 months, followed by the South ( 2.5 months), Southeast ( 2 months), and Central West (1.5 months) regions. Favorable and statistically significant changes were found in 14 capital cities. Interestingly, in Belém, where we found the highest median of BF duration in 1999 (566.3 days), there was a more significant reduction in 2008 (121 days). A more favorable evolution was found in Maceió, with an increase of 159 days in the median of BF duration.

Figure 1 shows the correlation graphs between BF status in 1999 and the degree of evolution of the EBF and BF medians during the period. There was a negative correlation between the 1999 median duration and the evolution percentage in

Table 3 - Evolution of the median duration of breastfeeding (Brazil, regions and capital cities, 1999 to 2008)

\begin{tabular}{|c|c|c|c|c|c|c|}
\hline \multirow[b]{2}{*}{ Region/capital city } & \multicolumn{2}{|c|}{1999} & \multicolumn{2}{|c|}{2008} & \multirow[b]{2}{*}{$\Delta(\mathbf{b}-\mathbf{a})$} & \multirow{2}{*}{$\begin{array}{c}\text { Evolution } \\
\qquad(\%)\end{array}$} \\
\hline & Mediana & $95 \% \mathrm{CI}$ & Median'b & $95 \% \mathrm{CI}$ & & \\
\hline North & 414.2 & $388.0-442.3$ & 434.8 & $410.4-464.9$ & 20.6 & 4.97 \\
\hline Rio Branco & 311.5 & $271.7-357.1$ & 376.0 & $330.1-453.9$ & 64.5 & 20.71 \\
\hline Manaus & 351.4 & 296.3-416-1 & 418.1 & $379.0-475.4$ & 66.7 & 18.98 \\
\hline Macapá & 515.3 & $436.5-608.2$ & 601.4 & $498.7-810.4$ & 86.1 & 16.71 \\
\hline Palmas & 336.5 & $300.6-376.7$ & 379.3 & $344.9-429.8$ & 42.8 & 12.72 \\
\hline Porto Velho & 392.2 & $331.6-463.9$ & 434.6 & $382.0-527.6$ & 42.4 & 10.81 \\
\hline Boa Vista & 429.2 & $342.0-538.6$ & 418.8 & $378.7-479.3$ & -10.4 & -2.42 \\
\hline Belém & 566.3 & $434.0-739.0$ & 445.2 & $404.1-504.5$ & -121.1 & -21.38 \\
\hline Northeast* & $252.8^{*}$ & $244.5-261.4$ & 346.8 & $333.3-362.3$ & $94.0 *$ & 37.18 \\
\hline Maceió* & 172.0 & $158.6-186.5$ & 331.5 & $296.5-384.3$ & 159.5 & 92.73 \\
\hline Aracaju* & 229.0 & $208.0-252.0$ & 377.4 & $326.0-471.5$ & 148.4 & 64.80 \\
\hline João Pessoa* & 198.4 & $181.6-216.8$ & 314.1 & $290.9-344.7$ & 115.7 & 58.32 \\
\hline Recife* & 196.8 & $175.6-220.7$ & 293.1 & 278.7-309.9 & 96.3 & 48.93 \\
\hline Fortaleza* & 224.7 & $215.0-234.9$ & 332.8 & $307.3-366.3$ & 108.1 & 48.11 \\
\hline Natal* & 230.8 & $203.8-261.3$ & 330.0 & $307.0-359.7$ & 99.2 & 42.98 \\
\hline Salvador* & 274.6 & 241.9-311.6 & 351.6 & $322.7-391.0$ & 77.0 & 28.04 \\
\hline São Luís & 439.4 & $365.5-528.2$ & 480.2 & $414.8-598.2$ & 40.8 & 9.29 \\
\hline Teresina & 478.4 & $402.1-569.1$ & 456.5 & $398.3-555.8$ & -21.9 & -4.58 \\
\hline Central West & $329.5 *$ & $313.4-346.4$ & 373.7 & $353.8-398.1$ & 44.2 & 13.41 \\
\hline Campo Grande* & 315.0 & $282.2-351.6$ & 406.0 & $363.0-471.7$ & 91.0 & 28.89 \\
\hline Goiânia* & 260.9 & $239.6-284.1$ & 310.9 & $288.5-340.4$ & 50.0 & 19.16 \\
\hline Cuiabá & 357.1 & $314.1-406.0$ & 389.9 & $346.1-460.3$ & 32.8 & 9.19 \\
\hline Federal District & 369.9 & $339.5-403.0$ & 383.6 & $354.2-424.2$ & 13.7 & 3.70 \\
\hline Southeast & $240.6^{*}$ & $227.3-254.6$ & 303.5 & 288.8-320.9 & 62.9 & 26.13 \\
\hline São Paulo & $180.8 *$ & $164.4-198.9$ & 292.8 & $273.7-316.8$ & 112.0 & 61.95 \\
\hline Belo Horizonte & $211.4 *$ & $193.1-231.4$ & 300.7 & $276.3-333.3$ & 89.3 & 42.24 \\
\hline Vitória & 327.0 & $291.6-366.7$ & 364.7 & $334.4-406.3$ & 37.7 & 11.53 \\
\hline Rio de Janeiro & - & - & 334.1 & $315.7-356.6$ & - & \\
\hline South & $225.2^{*}$ & 211.3-239.9 & 302.1 & $286.2-321.0$ & 76.9 & 34.15 \\
\hline Porto Alegre & $193.5^{*}$ & $169.4-221.0$ & 299.3 & $274.2-333.2$ & 105.8 & 54.68 \\
\hline Curitiba & $221.9 *$ & $203.2-242.3$ & 300.8 & $278.2-330.4$ & 78.9 & 35.56 \\
\hline Florianópolis & $249.7^{*}$ & $221.2-282.0$ & 326.0 & $299.6-361.5$ & 76.3 & 30.56 \\
\hline Brazil & $295.9 *$ & 289.3-302.7 & 341.6 & $331.8-352.4$ & 45.7 & 15.44 \\
\hline
\end{tabular}

$95 \% \mathrm{Cl}=95 \%$ confidence interval.

* Difference between statistically significant medians. 

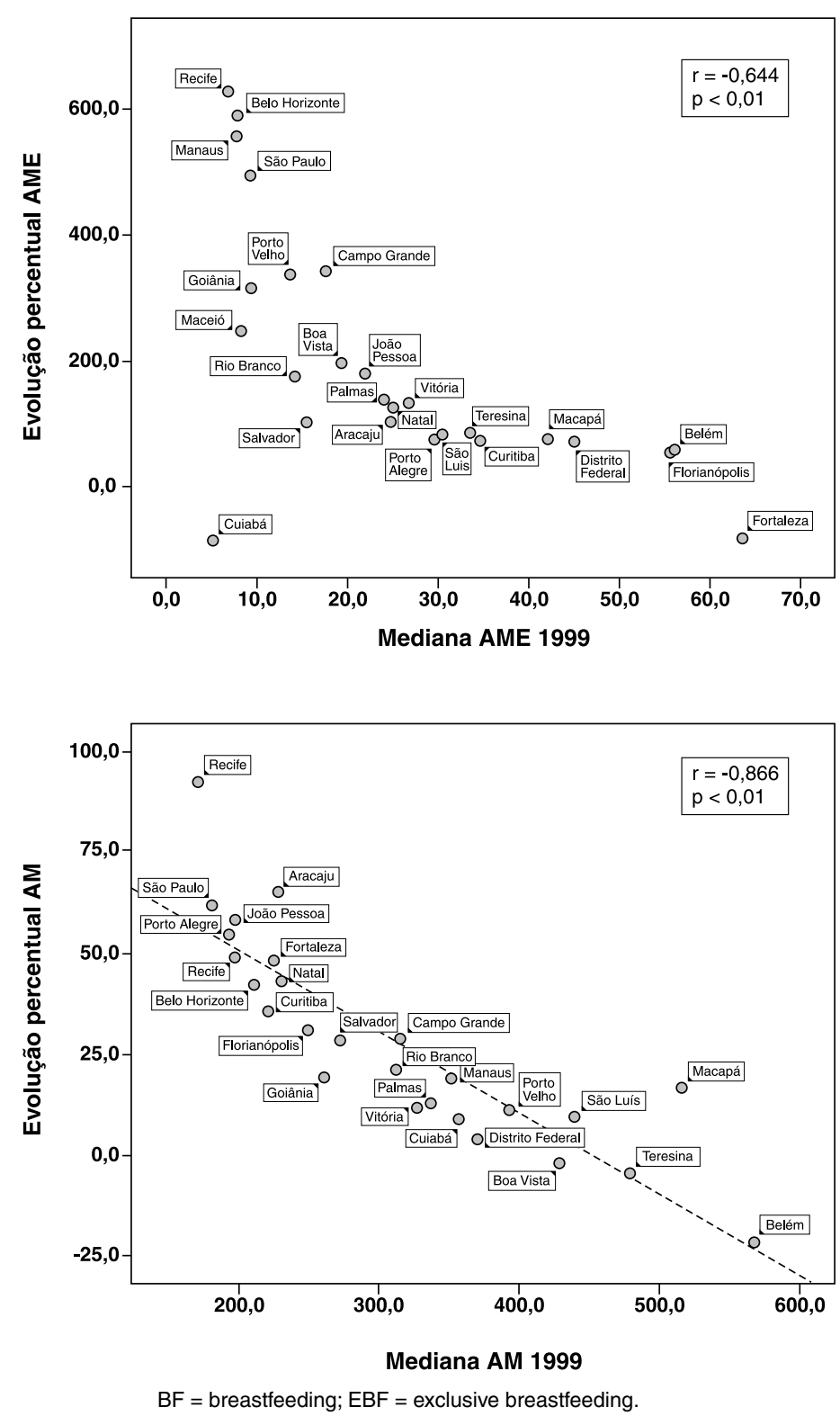

Figure 1 - Correlation between medians of breastfeeding and exclusive breastfeeding in 1999 in the Brazilian capital cities and the Federal District and its percentage evolution for the period from 1999 to 2008

both cases. In the capital cities where the median of BF duration was lower in 1999, such as in Maceió, São Paulo and Porto Alegre, there was a higher percentage increase and, on the other hand, in Belém, Teresina, and Boa Vista, capital cities with a more favorable status in 1999, there was even a reduction of the median of BF duration.

\section{Discussion}

The 2nd PPMA evidenced the current BF status and made it possible to analyze its evolution over the last decade in the Brazilian capital cities and the FD.
First, it is important to highlight some aspects related to the study design. To conduct studies during vaccination campaigns has been a strategy widely recommended and used in Brazil because it enables to collect data within a short period of time and at relatively low costs. ${ }^{13}$ Furthermore, the wide population coverage of the campaigns, combined with the use of sampling designs such as the one used in the present study, make it possible to achieve probability samples that are representative of the population of children under 1 year old in the cities studied.

Thus, concerning the external validity of the study, the following are positive aspects: the wide coverage of the 
second stage of the 2008 vaccination campaign (over $80 \%$ in all capital cities and a mean of $95 \%$ for Brazil) ${ }^{14}$ and the fact that the profile of maternal education (considered in this study as a proxy for socioeconomic status) is similar when comparing the sample analyzed with data from the Information System of Live Births in 2008 (86.2\% under 12 years of schooling vs. $83.8 \%$, respectively). ${ }^{15}$

A limitation of the present study is related to the noninclusion of population living in rural areas and smaller municipalities. ${ }^{16}$ On the other hand, the additional advantages of questionnaires administered during vaccination campaigns are: feasibility of shorter intervals, allowing the evaluation and planning of actions at local level, and its potential for the involvement of municipal medical teams and interviewers, usually recruited from universities

Two other aspects should be highlighted. The first one concerns the heterogeneity of the indicators between the capital cities and the regions of the country, reinforcing the importance of local research; the second aspect refers to the advances seen in BF practice.

The percentage of children breastfed within the first hour of life $(67.7 \%)$ surpassed that found in the 2006 PNDS $(43 \%)$ in a sample of children younger than 60 months. ${ }^{7}$ This difference may be partly explained by the fact that our questionnaire reflects a more recent status of children under 1 year. It was not possible to assess the evolution of this indicator because the 1999 study did not include that information. Its inclusion in the present study was due to the recent recommendation of the $\mathrm{WHO}^{12}$ and to recent reports about the impact of this practice on the decrease in neonatal mortality. ${ }^{2,3}$

The prevalence of EBF in children from 0 to 6 months $(41 \%)$ was very similar to that previously identified in the 2006 PNDS (39.8\%). ${ }^{7}$ The increase of about 1 month in the median of EBF found in the present study was higher than that found when comparing the 1996 PNDS (median of 1.1 months) with the 2006 study (median of 1.4 months). ${ }^{7}$ It is noteworthy, however, that the comparison between the EBF of the 1996 PNDS and the 2006 study should be cautiously interpreted since the 1996 data may be overestimated because of problems during data collection. ${ }^{8}$ A growing trend of EBF has been found in several studies conducted in Brazilian cities ${ }^{17-19}$ and other countries .20-22

The BF indicator in children between 9 and 12 months was used as an indicator of BF continuity. For calculating this indicator, the WHO recommends using the proportion of breastfed children aged from 12 to 15.9 months, but as our study included children under 1 year old, we decided to use the age group between 9 and 12 months.

BF continuity had a very heterogeneous behavior between capital cities and regions, ranging from $49.5 \%$ in the South to $76.9 \%$ in the North. The median of BF found in the present study was 11.2 months, which was lower than that found in the 2006 PNDS (14.0 months) ${ }^{7}$; but the median of BF in urban areas of the country found in the 2006 PNDS was 12.9 months, ${ }^{7}$ that is, more similar to our study. Interestingly, despite the increase observed in BF continuity in Brazil, its median is still lower than that found by Pérez-Escamilla ${ }^{21}$ in Bolivia (17.5 months), Guatemala (19.9 months), and Peru (19.5 months) in the 1990s.

The WHO recommends EBF until 6 months and continuing BF along with complementary foods for 2 years or longer. ${ }^{23}$ According to the parameters suggested by the $\mathrm{WHO},{ }^{24}$ the figures revealed by the present study are far from ideal. Regarding EBF in children under 6 months, 23 capital cities showed rates considered "fair" (prevalence between 12 and $49 \%$ ), and only four (Belém, Campo Grande, Brasília, and Florianópolis) were considered to have "good status" (between 50 and $89 \%$ ). In terms of BF duration, the status is considered to be "poor" in most cases (median lower than 17 months) and only Macapá is classified as having a "fair" status (median between 18 and 20 months).

Although the BF status is far from ideal, the advances made towards the expansion of the BF practice in Brazil is undeniable. Although the identification of the factors that led to this improvement goes beyond the scope of the present study, for contextualization purposes, it is important to point out some changes in the socioeconomic profile of the population and the development of the national policy for $\mathrm{BF}$, because these are factors that may have influenced this behavior.

Maternal educational level, identified as an important factor associated with BF practices, ${ }^{25}$ improved considerably between 1999 and 2008, with an increase of 20.4 percentage points for mothers with educational level between 8 and 11 years. ${ }^{15}$

The role of policies and programs in the expansion of $\mathrm{BF}$ practice has also been reported by several authors. 16,20-22,24 In this sense, the following initiatives stand out in Brazil: the expansion of the Brazilian Network of Human Milk Banks, currently composed of 270 units, which recorded a $56 \%$ increase in milk collection between 2003 and 2008, 50\% more children benefited and double number of donors, which now totals 113,00026; the expansion of the BabyFriendly Hospital Initiative between 1999 and 2008, with accreditation of 52 hospitals in 2002 and 43 in 200327; advances related to the Brazilian Code of Marketingof Breastmilk Substitutes (Norma Brasileira de Comercialização de Alimentos para Lactentes e Crianças de Primeira Infância, Bicos, Chupetas e Mamadeiras - NBCAL), resulting from changes in that legislation implemented in 2002 and the creation of the Law 11,625, published in 2006, aimed at regulating the marketing and guidance of the appropriate use of food for children under 3 years 28 ; and, finally, the intense social mobilization triggered by the celebration of World Breastfeeding Weeks, and the implementation of the National Day of Human Milk Donation in October 1.29 
The analysis of the influence of BF status in 1999 on the behavior of the indicators in 2008 clearly showed that there was a higher increase in the capital cities that had a worse status in 1999 and, on the other hand, there were more discreet advances or even setbacks in places where the status was more favorable. The cities of Belém and Fortaleza, for example, which in 1999 had the highest medians of BF and EBF, respectively, not only did not show any progress, but also had setbacks. This context evidences the need for Brazil to invest in new strategies to encourage BF so that its indicators reach higher levels. Accordingly, in 2008 the Brazilian Ministry of Health launched the Brazilian Breastfeeding Network (Rede Amamenta Brasil), aiming to promote and support BF in the primary health care network of the country. This strategy fills a major gap, considering the fact that the actions to stimulate BF are focused on hospital settings.

It is possible to conclude that there was a significant improvement in the BF status in the last decade, considering all Brazilian capital cities, with persistent differences between the regions and capital cities analyzed. However, there is still need of a great effort so that Brazil can achieve $\mathrm{BF}$ rates compatible with the WHO recommendations. We hope that the data provided by the present study are used by managers, health professionals, and the society to provide support for planning and evaluation of actions that promote $\mathrm{BF}$.

\section{References}

1. Jones G, Steketee RW, Black RE, Bhutta ZA, Morris SS; Bellagio Child Survival Study Group. How many child deaths can we prevent this year? Lancet. 2003;362:65-71.

2. Edmond KM, Zandoh C, Quigley MA, Amenga-Etego S, OwusuAgyei S, Kirkwood BR. Delayed breastfeeding initiation increases risk of neonatal mortality. Pediatrics. 2006;117:380-6.

3. Mullany LC, Katz J, Li YM, Khatry SK, LeClerq SC, Darmstadt GL, et al. Breast-feeding patterns, time to initiation, and mortality risk among newborns in southern Nepal. J Nutr. 2008;138:599-603.

4. Rea MF. The Brazilian National Breastfeeding Program: a success story. Int J Gynecol Obstet. 1990;31:79-82.

5. Venancio SI, Monteiro CA. A evolução da prática da amamentação nas décadas de 70 e 80. Rev Bras Epidemiol. 1998;1:40-9.

6. Sociedade Civil Bem-Estar Familiar no Brasil. Pesquisa Nacional sobre Demografia e Saúde. Rio de Janeiro: BEMFAM; 1997. p.125-38.

7. Brasil. Ministério da Saúde. Pesquisa Nacional de Demografia e Saúde da Criança e da Mulher - PNDS 2006. Brasília: Ministério da Saúde; 2009. p.195-212.

8. Monteiro CA. O panorama da nutrição infantil nos anos 90 . Brasília: UNICEF; 1997. (Cadernos de Políticas Sociais, Série Documentos para Discussão, v. 1).

9. Brasil. Ministério da Saúde. Prevalência de Aleitamento Materno nas Capitais Brasileiras e no Distrito Federal. Brasília: Ministério da Saúde; 2001.

10. Brasil. Ministério da Saúde. Secretaria de Atenção à Saúde. Departamento de Ações Programáticas e Estratégicas. II Pesquisa de Prevalência de Aleitamento Materno nas Capitais Brasileiras e Distrito Federal. Brasília: Editora do Ministério da Saúde, 2009.

11. Silva NN. Amostragem Probabilística: um curso introdutório. São Paulo: EDUSP, 1998.
12. World Health Organization. Indicators for assessing infant and young child feeding practices: conclusions of a consensus meeting held 6-8 November 2007 in Washington D.C., USA. Geneva: WHO; 2008.

13. Santos LM, Paes-Sousa R, Silva Junior JB, Victora CG. National Immunization Day: a strategy to monitor health and nutrition indicators. Bull World Health Organ. 2008;86:474-9.

14. Brasil. Ministério da Saúde. Sistema de informação do Programa Nacional de Imunizações. http://pni.datasus.gov.br. Access: 10/03/2010.

15. Brasil. Ministério da Saúde. Sistema de Informações sobre Nascidos Vivos - SINASC. Situação da base de dados nacional em 14/12/2009. http://tabnet.datasus.gov.br/cgi/tabcgi.exe?sinascp/cnv/nvuf. def. Access: 12/03/2010.

16. Rea MF. Reflexões sobre a amamentação no Brasil: de como passamos a 10 meses de duração. Cad Saude Publica. 2003;19 Suppl 1:S37-S45.

17. Brunken GS, Silva SM, França GV, Escuder MM, Venâncio SI. Risk factors for early interruption of exclusive breastfeeding and late introduction of complementary foods among infants in midwestern Brazil. J Pediatr (Rio J). 2006;82:445-51.

18. Ferreira L, Parada CM, Carvalhaes MA. Tendência do aleitamento materno em município da região centro-sul de estado de São Paulo: 1995-1999-2004. Rev Nutr. 2007;20:265-73.

19. Albernaz E, Araújo CL, Tomasi E, Mintem G, Giugliani E, Matijasevich $A$, et al. Influence of breastfeeding support on the tendencies of breastfeeding rates in the city of Pelotas (RS), Brazil, from 1982 to 2004. J Pediatr (Rio J). 2008;84:560-4.

20. Grummer-Strawn LM. The effect of changes in population characteristics on breastfeeding trends in fifteen developing countries. Int J Epidemiol. 1996;25:94-102.

21. Pérez-Escamilla R. Breastfeeding and the nutritional transition in the Latin American and Caribbean Region: a success story? Cad Saude Publica. 2003;19:S119-27.

22. Labbok MH, Wardlaw T, Blanc A, Clark D, Terreri N. Trends in exclusive breastfeeding: findings from the 1990s. J Hum Lact. $2006 ; 22: 272-6$.

23. World Health Organization. The optimal duration of exclusive breastfeeding. Note for the Press No 7. Geneva : WHO, 2001.

24. World Health Organization. Infant and Young Child Feeding: A tool for assessing breastfeeding practices, policies and programs. Geneva: WHO; 2003.

25. Venancio SI, Monteiro CA. Individual and contextual determinants of exclusive breastfeeding in São Paulo, Brazil: a multilevel analysis. Public Health Nutr. 2006; 9:40-6.

26. FIOCRUZ. Rede de Bancos de Leite Humano. http://www. redeblh. fiocruz.br/cgi/cgilua.exe/sys/start.htm?sid=352. Access: 15/10/2009.

27. Brasil. Ministério da Saúde. A Iniciativa Hospital Amigo da Criança no Brasil: histórico, situação atual, ações e perspectivas. http://portal.saude.gov.br/portal/saude/area.cfm?id_area=1460. Access: 15/10/2009.

28. de Fátima Moura de Araújo M, Rea MF, Pinheiro KA, de Abreu Soares Schmitz B. Avanços na norma brasileira de comercialização de alimentos para idade infantil. Rev Saude Publica. 2006;40:513-20.

29. Alencar SM. A Política Nacional de Aleitamento Materno. In: O aleitamento materno no contexto atual. Políticas, práticas e bases científicas. São Paulo: Sarvier; 2008. p. 70-101.

Correspondence:

Sonia I. Venancio

Rua Santo Antônio, 590/50 andar - Bela Vista

CEP 01314-000 - São Paulo, SP - Brazil

Tel.: + 55 (11) 3293.2278

Fax: +55 (11) 3105.2772

E-mail: soniav@isaude.sp.gov.br 